\title{
Gene mapping in the river buffalo (Bubalus bubalis L)
}

\author{
HA de Hondt ${ }^{1}$, AA Bosma ${ }^{2}$, $\mathrm{M}$ den Bieman ${ }^{3}$, \\ NA de $\operatorname{Haan}^{3}$, LFM van Zutphen ${ }^{3}$ \\ 1 National Research Centre, Unit of Cell Biology, Dokki, Egypt; \\ 2 Utrecht University, Faculty of Veterinary Medicine, \\ Department of Cell Biology and Histology, and \\ 3 Department of Laboratory Animal Science, The Netherlands
}

(Proceedings of the 9th European Colloquium on Cytogenetics of Domestic Animals; Toulouse-Auzeville, 10-13 July 1990)

river buffalo / gene mapping / somatic cell hybrids / enzymes / enzyme gene loci

Somatic cell hybridization was used as a tool to examine synteny of genes in the buffalo. Parental cells were blood lymphocytes from two Egyptian river buffaloes, and cells of the HPRT ${ }^{-}$(hypoxanthine phosphoribosyltransferase-negative) Chinese hamster cell line wg3h $\mathrm{cl}_{2}$ (Echard et al, 1984). Hybrid cells were produced by polyethylene glycol (PEG)-mediated fusion, followed by hypoxanthine-aminopterinethymidine (HAT) selection. Twenty-one independent hybrid cell lines were established. For enzyme analysis, hybrid cells and hamster cells were lysed in lysis buffer (Meera Khan, 1971). Buffalo cardiac muscle, skeletal muscle and erythrocytes were homogenized in the same buffer, and were used as samples of reference for buffalo enzyme activity. Starch gel electrophoresis (Harris and Hopkinson, 1978) was carried out to analyze the following enzymes: glyceraldehyde-3-phosphate dehydrogenase (GAPD; EC 1.2.1.12); lactate dehydrogenase (LDH; EC 1.1.1.27); malic enzyme (ME; EC 1.1.1.40); phosphoglucomutase (PGM; EC 5.4.2.2); superoxide dismutase (SOD; EC 1.15.1.1.); triose-phosphate isomerase (TPI; EC 5.3.1.1). Two different buffer systems were used for the separation of hamster enzymes from buffalo enzymes: a Tris/borate/EDTA (ethylenediaminetetraacetic acid) system, $\mathrm{pH}$ 8.6, (Shows et al, 1964) for LDH, ME and SOD, and a Tris/citrate system, pH 6.2, (Nichols and Ruddle, 1973) for GAPD. For PGM and TPI, both buffer systems were used. After electrophoresis ( $5 \mathrm{~h}$, maximum $30 \mathrm{~mA}$ or $300 \mathrm{~V} / \mathrm{gel}$ ), gels were stained for enzyme activity according to Harris and Hopkinson (1978). The nomenclature for the buffalo enzymes is based on the concept of homology. Abbreviations and criteria for homology are in agreement with the ISGN system (Human Gene Mapping 5, 1979). Zymograms are presented in figure 1.

Buffalo tissues and hamster cells showed one zone of GAPD activity, with different mobility. The 3 intermediate zones in hybrids expressing buffalo GAPD indicate a tetrameric structure of this enzyme. 
GAPD

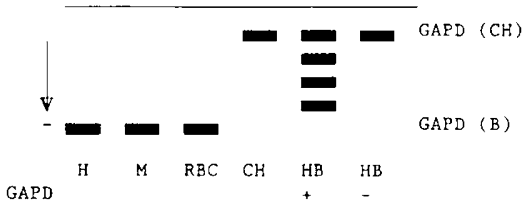

ME

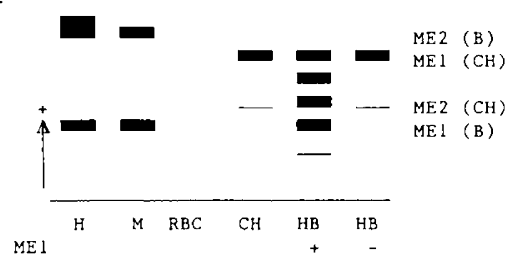

SOD

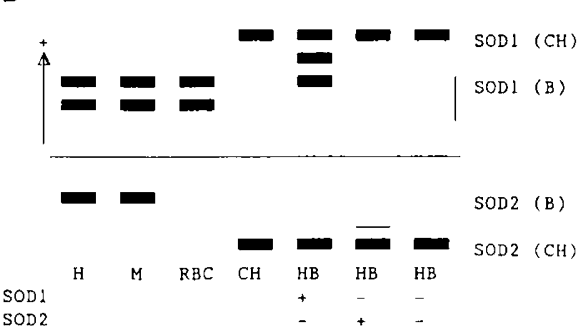

$\mathrm{LDH}$

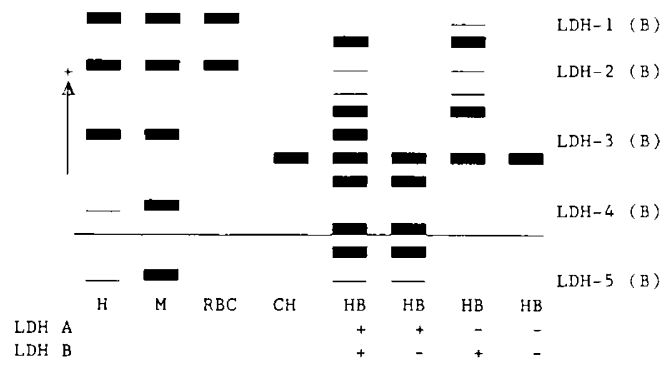

PGM
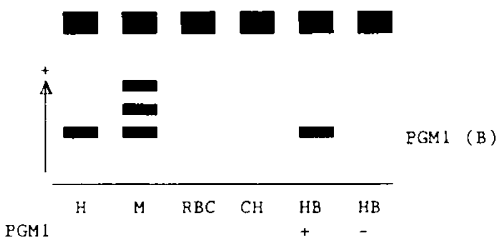

TPI

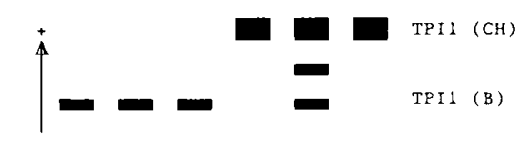

Fig 1. Diagrammatic representation of zymograms of GAPD, LDH, ME, PGM, SOD and TPI. H: buffalo cardiac muscle; $\mathbf{M}$ : buffalo skeletal muscle; RBC: buffalo erythrocytes; $\mathbf{C H}$ : Chinese hamster ccll line wg3h $\mathrm{cl}_{2} ; \mathbf{H B}+$ : hybrid expressing buffalo enzyme; HB -: hybrid not expressing buffalo enzyme.

LDH is a tetrameric enzyme coded for by two separate genes, LDHA and LDHB. In buffalo tissues, 5 isozymes (LDH-1-LDH-5) could be distinguished. These may be considered as being composed of different combinations of the $\mathrm{A}$ and $\mathrm{B}$ subunits, subunit $A$ being the main subunit in skeletal muscle $(M)$ and subunit $B$ being the main subunit in cardiac muscle $(\mathrm{H})$ and erythrocytes ( $\mathrm{RBC})$. In the hybrid panel, all 4 combinations of presence or absence of buffalo LDHA and LDHB were found.

Two forms of ME, the cytosolic enzyme ME1 and the mitochondrial enzyme ME2, could be distinguished. Probably, both forms are tetramers (Povey et al, 
1975). From the relative activity of the two ME zones in buffalo tissues, and by comparison with the relative mobility as found for bovine ME (Heuertz and Hors-Cayla, 1981), it was concluded that the most anodal zone represents buffalo ME2, and the more cathodal zone buffalo ME1. In hybrids expressing buffalo ME1, intermediate zones could be detected. Buffalo ME2 was not found in any of the hybrid cell lines.

In man, 3 genes are described for PGM (Harris and Hopkinson, 1978). The relative migration order of bovine enzymes is the same as that of human enzymes., $i e$, from cathode to anode: PGM1, PGM2 and PGM3 (Heuertz and Hors-Cayla, 1981). The zone with the lowest mobility in buffalo tissues was also found in some of the hybrids. From its relative activity and relative mobility, it was concluded that this zone represents buffalo PGM1. The absence of intermediate zones in hybrids expressing buffalo PGM1 indicates that this enzyme is a monomer.

In buffalo tissues, two separate zones of SOD activity were found. From the absence of the cathodal zone in erythrocytes (RBC), and by comparison with zymograms of other species (van Someren et al, 1974; McAvin et al, 1988), it was concluded that the anodal zones represent the cytosolic enzyme SOD1 and the cathodal zone the mitochondrial enzyme SOD2. The one intermediate zone in hybrids expressing buffalo SOD1 indicates a dimeric structure for this enzyme. Human SOD2 has been proven to be a tetramer (Harris and Hopkinson, 1978). No buffalo SOD2 activity could be detected in any of the hybrids at the site corresponding to SOD2 in buffalo tissues. The conclusion that buffalo SOD2 is expressed in hybrids is based on the presence of one minor intermediate zone, and the supposition that hamster SOD2 is far more active than buffalo SOD2.

Human TPI1 is a dimeric enzyme present in all tissues (Harris and Hopkinson, 1978). Many secondary isozymes can be detected; their number varies with the type of tissue and the buffer system used for separation. In the buffalo tissues as well as in the hamster and hybrid cells, secondary isozymes of minor activity were found (not shown). In buffalo tissues and hamster cells, one major zone of activity was detected. The one intermediate zone in hybrids expressing buffalo TPI1 indicates a dimeric structure for this enzyme.

The segregation pattern of buffalo genes in the panel of hybrid cell lines investigated is given in table I. Independence of presence or absence of two genes was analyzed using the $\chi^{2}$ test with Yates' correction for $2 \times 2$ contingency tables. Synteny was concluded when $P<0.01$. By this criterion, GAPD, LDHB, TPI1, ME1 and SOD2 can be considered syntenic. LDHA, PGM1 and SOD1 segregate independently from each other and from the two syntenic groups $(P>0.01)$, and are probably located on separate chromosomes.

The genes found to be syntenic in the buffalo are also syntenic in Bos taurus cattle (Fries et al, 1989), and in man (Human Gene Mapping 10, 1989). This indicates conservation of genomic segments in these 3 species. In the mouse, synteny exists for GAPD, LDHB and TPI1, but not for ME1 and SOD2 (Mouse Genome, 1990). The 3 genes found to segregate independently in the buffalo belong to independent groups in the 3 other species as well.

The conformity of synteny and asynteny between buffalo and cattle is consistent with the concept of chromosome conservation within the family Bovidae. 
Table I. Buffalo enzyme activity detected (+) or not (-) in 21 independent buffalohamster hybrid cell lines.

\begin{tabular}{ccccccccc}
\hline $\begin{array}{c}\text { Hybrid } \\
\text { no }\end{array}$ & GAPD & TPI1 & LDHB & ME1 & SOD2 & LDHA & PGM1 & SOD1 \\
\hline A1 & - & - & - & - & - & + & - & - \\
A2 & - & - & - & - & - & - & - & - \\
B1 & - & - & - & - & - & - & - & - \\
B2 & + & + & + & - & - & + & - & - \\
B3 & - & - & - & - & - & - & - & - \\
B4 & - & - & - & - & - & - & - & - \\
B5 & - & - & - & + & + & - & - & - \\
B6 & + & + & - & - & - & + & - & - \\
B7 & - & - & - & - & - & - & - & - \\
B8 & - & - & - & - & - & - & - & - \\
B9 & + & + & + & - & - & + & + & + \\
B11 & - & - & - & - & - & + & - & + \\
B12 & - & - & + & - & - & - & - & - \\
B13 & - & - & - & + & + & - & - & - \\
B14 & + & + & + & + & + & - & + & - \\
B15 & + & + & + & + & + & - & + & - \\
B16 & - & - & - & - & - & + & - & - \\
B17 & - & - & - & - & - & - & - & + \\
B18 & - & - & - & - & - & - & - & - \\
B22 & + & + & + & + & + & + & + & + \\
B23 & + & + & + & + & + & + & - & + \\
\hline
\end{tabular}

\section{REFERENCES}

Echard G, Gellin J, Gillois M (1984) Localisation des gènes MPI, PKM2, NP sur le chromosome 3 du porc (Sus scrofa L) et analyse cytogénétique d'une lignée de hamster chinois issue de la DON (wg3h). Génét Sél Evol 16, 261-270

Fries R, Beckmann JS, Georges M, Soller M, Womack J (1989) The bovine gene map. Anim Génét 20, 3-29

Harris H, Hopkinson DA (1978) Handbook of enzyme electrophoresis in human genetics. North Holland Publ Co, Amsterdam

Heuertz S, Hors-Cayla MC (1981) Cattle gene mapping by somatic cell hybridization: study of 17 enzyme markers. Cytogenet Cell Genet 30, 137-145

Human Gene Mapping 5 (1979) International System for Human Gene Nomenclature. Cytogenet Cell Genet 25, 96-116

Human Gene Mapping 10 (1989) Tenth International Workshop on Human Gene Mapping. Cylogenet Cell Genet 51, 1-1148

McAvin JC, Patterson D, Womack JE (1988) Mapping of bovine PRGS and PAIS genes in hybrid somatic cells: syntenic conservation with human chromosome 21 . Biochem Genet $26,9-18$

Meera Khan P (1971) Enzyme electrophoresis on cellulose acetate gel: zymogram patterns in man-mouse and man-Chinese hamster somatic cell hybrids. Arch Biochem Biophys 145, 470-483

Mouse Genome (1990) (Mouse gene list) 86, 24-80 
Nichols EA, Ruddle FH (1973) A review of enzyme polymorphism, linkage and electrophoretic conditions for mouse and somatic cell hybrids in starch gels. $J$ Histochem Cytochem 21, 1066-1081

Povey S, Wilson DE, Harris H, Gormley IP, Perry P, Buckton KE (1975) Subunit structure of soluble and mitochondrial malic enzyme: demonstration of human mitochondrial enzyme in human-mouse hybrids. Hum Genet London 39, 203-212

Shows TB, Tashian RE, Brewer GJ (1964) Erythrocyte glucose-6-phosphate dehydrogenase in Caucasians: new inherited variant. Science 145, 1056-1057

van Someren H, Beijersbergen van Henegouwen H, Los W, Wurzer-Figurelli E, Doppert B, Vervloet M, Meera Khan P (1974) Enzyme electrophoresis on cellulose acetate gel. II. Zymogram patterns in man-Chinese hamster somatic cell hybrids. Humangenetik 25, 189-201 